Journal of Chromatography, 528 (1990) 267-273

Blomedical Applications

Elsevier Science Publishers B V., Amsterdam - Printed in The Netherlands

\title{
Note
}

\section{Quantification of cibenzoline and its imidazole metabolite by high-performance liquid chromatography in human serum}

\author{
V. KÜHLKAMP*, F. SCHMID, K M RESS, B.K. KRÄMER, F. MAYER, H.M. LIEBICH, \\ T. RISLER and L. SEIPEL
}

Medizinische Klinck Abteilung II, Otfrued Muller Strasse 10, D-7400 Tubingen (F R.G)

(First received June 21st, 1989; revised manuscript received January 2nd, 1990)

Cibenzoline, 4,5-dihydro-2-(2,2-diphenylcyclopropyl)- $1 H$-imidazole, is a new class 1 antiarrhythmic drug chemically not related to any other class 1 antiarrhythmic agent. The imidazole metabolite of cibenzoline, 2-(2,2-diphenylcyclopropyl) - $1 \mathrm{H}$-imidazole (I), is almost devoid of antiarrhythmic action [1]. The efficacy of cibenzoline has been shown by several investigators in the treatment of supraventricular and ventricular arrhythmias [2-7].

Although it is generally unnecessary to determine serum levels of antiarrhythmic drugs, the determination of plasma levels is recommended in cases of side-effects, unexplained failure of drug therapy and possible drug interactions [8].

The aim of the present study was to develop a simple but accurate highperformance liquid chromatographic (HPLC) method to determine cibenzoline and its metabolite (I) in human serum.

\section{EXPERIMENTAL}

Cibenzoline and its imidazole metabolite (I) were provided by Beiersdorf (Hamburg, F.R.G.). Acetonitrile, hydrochloric acid, triethylamine, dichloromethane and sodium hydroxide were obtained from Merck (Darmstadt, F.R.G.). 1-Octanesulphonic acid (PIC B-8 low-UV reagent) and dibutylamine 
phosphate (PIC D-4 reagent) were from Waters Assoc. (Eschborn, F.R.G.) and butylamine was from Fluka (Buchs, Switzerland). The internal standard, p-chlorodisopyramide, was obtained from Albert-Russell (Wiesbaden, F.R.G.).

\section{Instrumentation}

The HPLC system consisted of a Model 721 system controller, a 510 HPLC pump, a Wisp 710B injector block, a Lambda-Max Model 481 variable-wavelength detector and a Model 730 data module (Waters Assoc.).

\section{Chromatographic conditions}

The analysis was performed using a Nucleosil CN reversed-phase column ( $125 \mathrm{~mm} \times 4.6 \mathrm{~mm}$ I.D., particle size $5 \mu \mathrm{m}$; Grom, Herrenberg, F.R.G.) at room temperature $\left(20-24^{\circ} \mathrm{C}\right)$. The mobile phase consisted of $65 \%(\mathrm{v} / \mathrm{v})$ A $(971.5$ $\mathrm{ml}$ of water, $25 \mathrm{ml}$ of PIC B-8 low-UV reagent, $1 \mathrm{ml}$ of butylamine and $2.5 \mathrm{ml}$ of PIC D-4 reagent) and $35 \%(\mathrm{v} / \mathrm{v}) \mathrm{B}$ (acetonitrile). The flow-rate was 1.1 $\mathrm{ml} / \mathrm{min}$. The column effluent was monitored at $214 \mathrm{~nm}$, using a detector range of 0.05 a.u.f.s. and a chart speed of $0.4 \mathrm{~cm} / \mathrm{min}$. The injected volume was 200 $\mu \mathrm{l}$.

\section{Standards}

Three stock standard solutions were prepared, containing $10 \mathrm{mg} / \mathrm{l}$ cibenzoline and $I$ and $15 \mathrm{mg} / \mathrm{l}$ internal standard in $0.01 \mathrm{M}$ hydrochloric acid, respectively. The solutions were stable for at least two months if stored at $4^{\circ} \mathrm{C}$. A standard working solution was obtained by combining aliquots of the stock solutions and diluting them with $0.01 M$ hydrochloric acid to concentrations of either $1.0 \mathrm{mg} / \mathrm{l}$ cibenzoline and I or $1.5 \mathrm{mg} / \mathrm{l}$ for the internal standard.

\section{Sample collection}

Serum was obtained by centrifugation at $900 \mathrm{~g}$ for $10 \mathrm{~min}$. Twenty-two drugfree serum samples from normal healthy volunteers (twelve male, ten female) were pooled (normal pool). Through serum levels of cibenzoline from eighteen patients treated with cibenzoline for chemical conversion of atrial fibrillation were obtained at the fifth day of oral treatment. Prior to the therapy with cibenzoline a serum sample was obtained and analysed from these patients to exclude interference with cibenzoline, I or the internal standard from co-medication in these patients. Co-medication was not changed during the treatment with cibenzoline and consisted of phenprocoumone $(n=18)$, furosemide $(n=5)$, hydrochlorthiazide $(n=6)$, triamterene $(n=6)$, metildigoxin $(n=12)$, digitoxin $(n=6)$, verapamil $(n=9)$ and ranitidine $(n=3)$. Serum samples of patients treated with therapeutic doses of digitoxin, metildigoxin, verapamil, nifedipine, nitrendipine, dihydralazine, metoprolol, betaxolol, furosemide, xipamide, hydrochlorothiazide, triamterene, spironolactone, enalapril, isosorbide-5-mononitrate, heparin, phenprocoumon, acetylsalicylic acid, diazepam 
and glibenclamide were analysed individually. None of these drugs was noted as an interfering spike in the determination of cibenzoline, I or the internal standard.

\section{Extraction procedure}

Dichloromethane $(1.75 \mathrm{ml}), 0.25 \mathrm{ml}$ of triethylamine, $1.0 \mathrm{ml}$ of serum, 100 $\mu \mathrm{l}$ of $1 M$ sodium hydroxide and $100 \mu \mathrm{l}$ of the stock solution of the internal standard were introduced into a glass centrifuge tube (Kästner, Tübingen, F.R.G.). The tube was closed with a stopper (Sarstedt, Nürmbrecht, F.R.G.), shaken (by slow rotation movement) for $20 \mathrm{~min}$ and centrifuged at $3600 \mathrm{~g}$ for $20 \mathrm{~min}$. Subsequently the serum phase was discarded, and $1.0 \mathrm{ml}$ of the dichloromethane-triethylamine phase was transferred to a clean glass tube and evaporated to dryness at room temperature $\left(20-24^{\circ} \mathrm{C}\right)$ under a stream of nitrogen. The residue was redissolved in $500 \mu \mathrm{l}$ of $0.01 \mathrm{M}$ hydrochloric acid.

\section{Linearity test}

The linearity of the chromatographic procedure was tested for cibenzoline, I and the internal standard by analysing nine standard solutions with concentrations of $4.0,3.0,2.0,1.5,1.0,0.5,0.25,0.1$ and $0.05 \mathrm{mg} / \mathrm{l}$ for each of the components (Fig. 1). At each concentration level three determinations were performed.

The amount of each standard required to reach concentrations in the range $0.05-4.0 \mathrm{mg} / \mathrm{l}$ was introduced into a glass centrifuge tube, and $1.0 \mathrm{ml}$ of the normal pool serum was added. Subsequently the spiked serum samples were extracted and subjected to the chromatographic analysis. The linearity test of the entire procedure in serum was done over the same concentration range (Fig. 2).

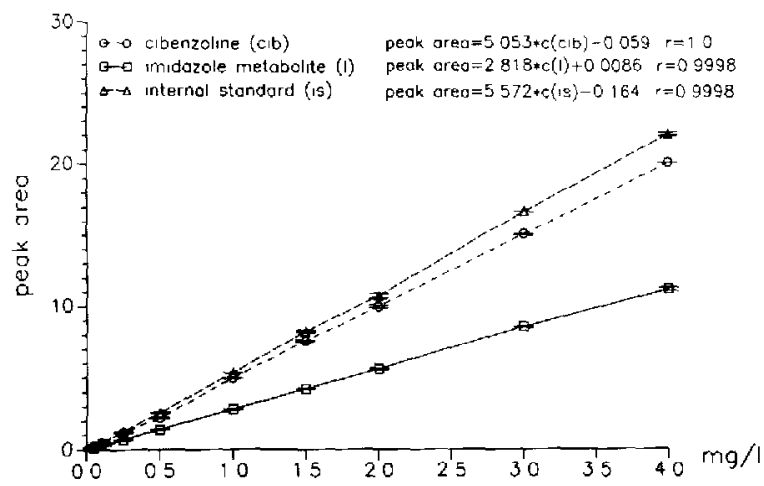

Fig. 1. Linearity test for $(O)$ cibenzoline, $(\square)$ the imidazole metabolite and $(\Delta)$ the internal standard in the standard solution. $c(\mathrm{cib})=$ concentration of cibenzoline; $c(\mathrm{I})=$ concentration of the imidazole metabolite; $c$ (is) $=$ concentration of internal standard. 


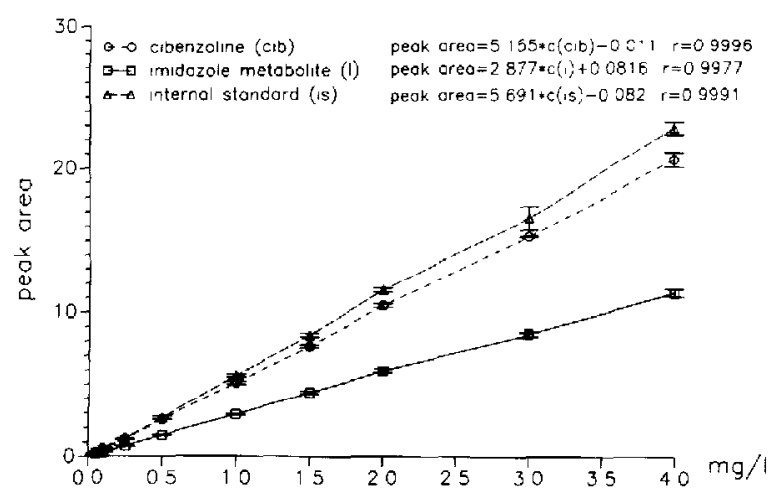

Fig. 2. Linearity test for $(O)$ cibenzoline, $(\square)$ the imidazole metabolite and $(\triangle)$ the internal standard in a spiked serum sample. $c(\mathrm{cib})=$ concentration of cibenzoline; $c(\mathrm{I})=$ concentration of the imidazole metabolite; $c$ (is) $=$ concentration of internal standard.

\section{Recoveries}

The recoveries were determined by comparing the peak areas of cibenzoline, I and the internal standard obtained by analysing a spiked serum sample (100 $\mu \mathrm{l}$ of each stock solution standard plus $1.0 \mathrm{ml}$ of the normal pool) with the peak areas obtained by direct injection of the standard working solution $(1.0 \mathrm{mg} / \mathrm{l}$ cibenzoline, $1.0 \mathrm{mg} / \mathrm{l} \mathrm{I}$ and $1.5 \mathrm{mg} / \mathrm{l}$ internal standard).

\section{Quantification}

Prior to injection of a sample from a patient, a sample of the working standard solution of cibenzoline, I and the internal standard containing $1 \mathrm{mg} / \mathrm{l}$ of each substance was injected. Since the linearity test showed a linear relationship between the peak area and the concentration of cibenzoline and I (Figs. 1 and 2), the concentrations of cibenzoline and I in the patient's sample were calculated as follows:

APS $1 \mathbf{~ m g} / 1$

ASW

$=$ concentration $(\mathrm{mg} / \mathrm{l})$ of cibenzoline or $\mathrm{I}$ in the patient's sample (CPS) where APS is the peak area of cibenzoline or I in the patient's sample and ASW is the peak area of cibenzoline or I in the standard working solution.

Since the recovery of cibenzoline and I in the patient's sample might change in various extractions we calculated the recovery rate by dividing the peak area of the internal standard in the patient's sample by the peak area of the internal standard in the standard working solution. Then

$\frac{\text { AISPS } \cdot 100}{\text { AISSW }}=$ recovery $(\%)$

where AISPS is the peak area of the internal standard in the patient's sample and AISSW is the peak area of the internal standard in the standard working solution. 
The calculated concentrations of cibenzoline and I were finally corrected for the recovery rate as follows:

$\frac{\mathrm{CPS}(\mathrm{mg} / \mathrm{l}) \cdot 100}{\text { recovery }(\%)}=$ final concentration of cibenzoline or I $(\mathrm{mg} / \mathrm{l})$

The recovery rates of cibenzoline, I and the external standard were the same within ca. $5 \%$.

\section{RESULTS}

For the standards and serum samples taken through the entire procedure there was a linear relationship between concentration and peak area over the total range tested. The recoveries (mean \pm S.D.) were $96.3 \pm 4 \%$ for cibenzoline $(n=10), 95.7 \pm 6.3 \%$ for I $(n=10)$ and $95.4 \pm 3.8 \%$ for the internal standard $(n=10)$. The technical error of the apparatus was determined for cibenzoline, I and the internal standard by injecting ten samples of the same standard working solution containing $1 \mathrm{mg} / \mathrm{l}$ cibenzoline, $1 \mathrm{mg} / 1 \mathrm{I}$ and $1.5 \mathrm{mg} / \mathrm{l}$ internal standard. The peak area of cibenzoline was $3.9589 \pm 0.0187$, that of I was $3.9589 \pm 0.0151$, and that of the internal standard was $4.3247 \pm 0.0394$.
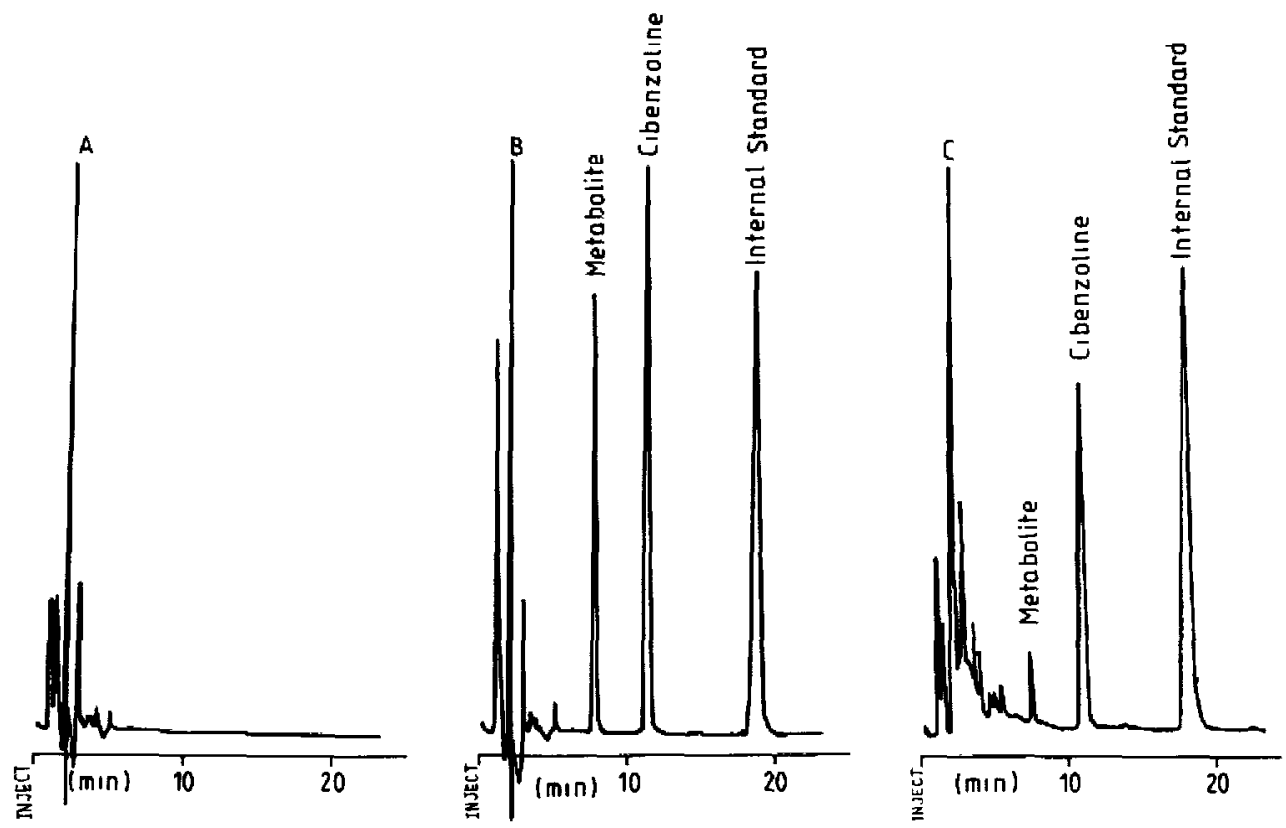

Fig. 3. Chromatograms of (A) a blank from the patient's pool, (B) a standard working solution and $(\mathrm{C})$ the serum of a patient receiving oral cibenzoline $(320 \mathrm{mg})$. 


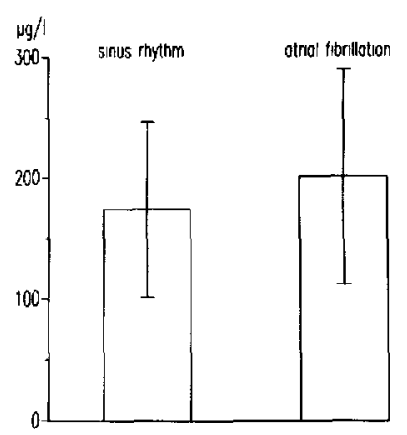

Fig. 4. Plasma levels $(\mu \mathrm{g} / \mathrm{l})$ in patients successfully converted to sinus rhythm $(n=6)$ and patients with persisting atrial fibrillation $(n=12)$.

A typical chromatogram obtained from the analysis of a serum sample of a patient receiving oral cibenzoline ( $320 \mathrm{mg}$ per day) is shown in Fig. 3.

Trough serum levels obtained with $260 \mathrm{mg}$ of cibenzoline $(0.156 \pm 0.067 \mathrm{mg} /$ $1, n=8$ ) daily were not significantly different from serum levels obtained in patients treated with $320 \mathrm{mg}$ of cibenzoline $(0.205 \pm 0.113 \mathrm{mg} / \mathrm{l}, n=10)$ daily. In the patient group receiving $260 \mathrm{mg}$ as well as in the patient group treated with $320 \mathrm{mg}$ of cibenzoline per day, three patients converted to sinus rhythm. Trough serum levels of cibenzoline were not significantly different between patients treated successfully with cibenzoline and patients with persisting atrial fibrillation (Fig. 4).

\section{DISCUSSION}

Four different methods for the determination of cibenzoline and its imidazole metabolite have been published. Canal et al. [9] used a gas chromatographic (GC) method, but the limit of detection was $30 \mathrm{ng} / \mathrm{ml}$ and the imidazole metabolite could not be determined. A gas chromatographic-mass spectrometric assay has been reported by Min and Garland [10], with a very good sensitivity of $1 \mathrm{ng} / \mathrm{ml}$. Although GC procedures are specific and sensitive they are not always available in clinical laboratories. A radioimmunoassay developed by Dixon et al. [11] showed good sensitivity, but the antiserum crossreacted almost $100 \%$ with the imidazole metabolite.

The only HPLC procedure reported [12] has a limit of quantitation of 10 $\mathrm{ng} / \mathrm{ml}$ and a moderate recovery rate of $60-70 \%$ : cibenzoline and the imidazole metabolite could not be determined simultaneously by this procedure, the recovery of the imidazole metabolite was $88.5 \pm 8.7 \%$ in plasma, and the limit of quantitation was $10 \mathrm{ng} / \mathrm{ml}$.

The limit of quantitation in the assay reported here is $10 \mathrm{ng} / \mathrm{ml}$, but the recovery is ca. $95 \%$ for cibenzoline. An advantage of our assay is the simulta- 
neous determination of cibenzoline and the imidazole metabolite. The recovery and the limit of detection for the imidazole metabolite are comparable with those of cibenzoline.

We determined cibenzoline serum levels in patients treated with cibenzoline for chemical conversion of newly developed atrial fibrillation or flutter. Successful conversion to sinus rhythm was achieved in six of eighteen patients; however, serum levels were not significantly different between responders to cibenzoline and non-responders (Fig. 4).

\section{CONCLUSION}

A sensitive, selective and easy-to-perform HPLC assay with a high recovery for simultaneous determination of cibenzoline and its imidazole metabolite has been developed. Serum levels of cibenzoline and its imidazole metabolite were determined in patients after oral treatment with cibenzoline for chemical conversion of atrial fibrillation.

\section{REFERENCES}

1 F.-J. Leinweber, A.C. Loh, A.J. Szuna, J.J. Carbone, T.H. Williams, G.J. Sasso, J.W. Tilley, D. Pace, P. Dahlen, J.I. Kovacs and I.R. Klevans, Xenobiotica, 13 (1983) 287.

2 N. Wasty, S. Saksena and M.J Barr, Am. Heart J., 110 (1985) 1181.

3 S.T. Rothbart and S. Saksena, Am. J. Cardiol., 57 (1986) 941.

4 A. Waleffe, A. Dufour, M.-F. Aymard and H. Kulbertus, Eur. Heart J , 6 (1985) 253.

5 D.S. Miura, G. Keren, V. Torres, B. Butler, K. Aogaichi and J.C. Somberg, Am. Heart J., 109 (1985) 827.

6 G. Cocco, C. Strozzi, R. Pansini, N. Rochat, R. Bulgarelli, A. Padula, C. Sfrisi and A. Kamal al Yassini, Eur. Heart J., 5 (1984 ( 108.

7 V. Kühlkamp, O. Ickrath, R. Haasis and L. Seipel, Z. Kardiol., 77 (1988) 595.

8 H.R. Ochs, Z. Kardiol., 73 (1984) 605.

9 M. Canal, B. Flouvat, D. Tremblay and A Dufour, Eur. J. Clin. Pharmacol., 21 (1983) 509.

10 B.H. Min and W.A. Garland, J. Chromatogr., 336 (1984) 403.

11 R. Dixon, J. Carbone, J. Tilley and Y.-Y. Liu, J. Pharm. Sci., 72 (1983) 100.

12 M.R. Hackman, T.L. Lee and M.A. Brooks, J. Chromatogr., 272 (1983) 347. 